\title{
Seeing Serendipity: James Hillier's View on the Invention of the Electron Microscope
}

While not a materials scientist himself, physicist James Hillier was instrumental in the development of one of the tools that has made materials science possible: the electron microscope. His involvement in this endeavor began during his days as a graduate student at the University of Toronto in 1937. Max Knoll and Ernst Ruska of the Technische Hochschule in Berlin had proven the concept of focusing electrons using magnetic lenses in 1931, and they had proceeded to build the first primitive transmission electron microscope. After visiting these scientists in Berlin, Eli F. Burton, the chair of the Department of Physics at the University of Toronto, was interested in building an improved version of the instrument. Hillier signed on to the project and, together with Albert Prebus, designed the first electron microscope in North America, which became known as the University of Toronto 1938 model. While at the university, Hillier invented the astigmator, a device that corrected the astigmatism of the electron lens; for this he was inducted into the National Inventors Hall of Fame in Akron, Ohio, in 1980.

We met at Dr. Hillier's home in Princeton on a Sunday morning in the spring of 2001. He introduced his poodle, Princess, who cozied up to me right away. Our conversation started across a clear expanse of dining room table, with only a small tape recorder and a pad of paper between us; by the end of our conversation, the table top was covered with books, magazines, and micrographs that illustrated various points that Dr. Hillier had made. He made frequent excursions into his study to return with a prized micrograph of the first virus ever seen with an electron microscope, or a remarkable painting he had done years ago when his ambitions were more artistic than scientific.

Finally, I just followed him into his study. The dark-paneled walls were covered with the awards of a lifetime, including a framed crayon drawing from the children of Brantford Elementary School in the Ontario town where Dr. Hillier grew up, which was presented to him during a visit to the school. As was evident in our conversation, teachers played a significant role in Dr. Hillier's life, and he has clear ideas about how the next generation should be taught.

We spoke for four hours - in storytelling fashion, frequently interrupted by laughterabout his scientific contributions over the years, his relationship with his colleagues, the role of chance in his life, and his views on management. With Princess monitoring the conversation for accuracy, I asked Dr. Hillier how he first became interested in microscopy.

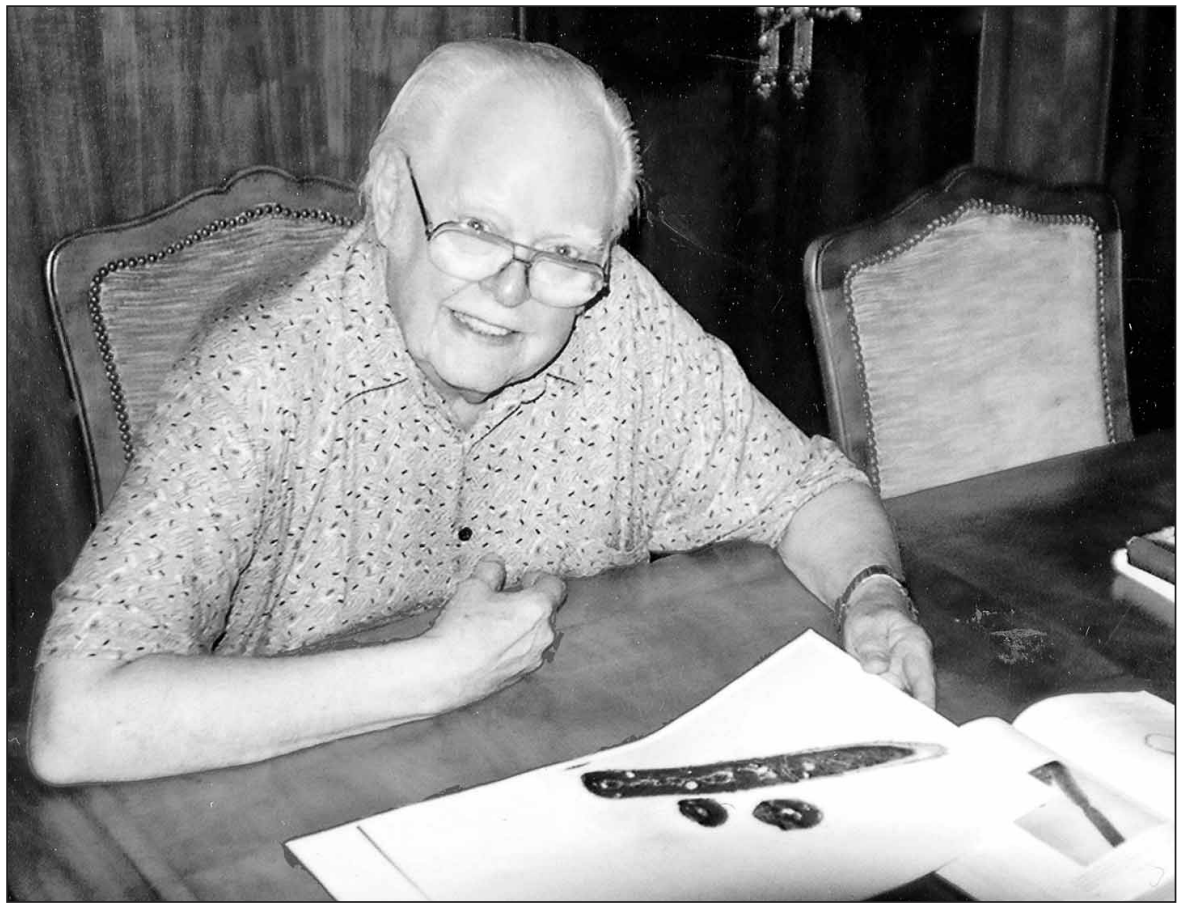

It started with the fact that my parents built a house in an abandoned apple orchard in Brantford, Ontario, way back in 1910 or 1911. Soon after, an airport bought a farm that was almost adjacent to the apple orchard for barnstorming-type airplanes. I was five or six years old and interested in airplanes-these were the biplanes made of wood and canvas. I was interested in every new plane I saw. When I realized that they all had different license numbers, I kept a list of the numbers to identify new airplanes. When I was a little older, I found out that I could read the license numbers on more airplanes by getting a telescope. So I made a telescope out of some crude lenses, but it wasn't very good.

When my father saw this makeshift telescope, he bought an honest-to-god telescope-one of these retractable types. It intrigued me because my homemade telescope inverted the image, but this telescope didn't. I discovered that it had an eye piece that inverted the image. The eye piece was a low-powered microscope in effect, with maybe a tenfold magnification. It had a little refractor lens out front,

Profiles \& Perspectives explores the people behind the profession of materials research. there was an image, it was upside down, and it was inverted by a low-power, twostage light microscope. I quickly found that I could take out the eye piece and look at anything and see it magnified. So I found pond water and saw the bugs that were running around in it, and it was interesting. I was sort of an amateur microscopist before I went to high school.

$$
\begin{aligned}
& \text { I was sort of an amateur } \\
& \text { microscopist before I went } \\
& \text { to high school. }
\end{aligned}
$$

Did this convince you at an early age that you wanted to be a scientist?

No. Through most of high school, I had the idea that I was going to be a commercial artist. Norman Rockwell was my role model. Then I ran into a new geography teacher. It is significant that I was born in 1915 , because this means, by pure accident, I was introduced to the geography teacher in his first year. That first year, he started a ham radio club. If I had been born a year earlier, I would have missed him; and if I'd been born a year later, the ham radio club would have been filled and I wouldn't have gotten in. I built a four-watt transmitter, and I talked to peo- 
ple as far away as New Orleans-it was unbelievable in those days. This geography teacher decided that I would probably make a better technical guy than an artist. He didn't see my art, so he never knew whether I was any good! Without my knowledge, he applied for a fellowship for me at the University of Toronto, provided that I would study mathematics and physics. When he was informed that I received the fellowship, he told me about it. So, suddenly I went to college and was doing math and physics, and it turned out I was pretty good at it and enjoyed it.

How did you become involved with electron microscopes?

Four years later, I was near graduation, and the assistant chair, named Eirton, said he hoped I'd be a graduate student, and I was because I didn't know where I was going to get a job right in the middle of the Great Depression. He listed the available research projects, including questions about liquid helium and measurement of the velocity of light electronically. But for each one, I thought to myself, "Boy, Hillier, you'll be the new man on the block on those projects, every one of which is going downhill."

Finally, Eirton was irritated with me and said, "Well, the director [Eli Burton] has a 'pet' project." I knew by the way he said "pet" that he didn't think very much of it. "It has something to do with electron microscopes."

I had never heard those two words put together before. Those two words together didn't make sense. What did electrons

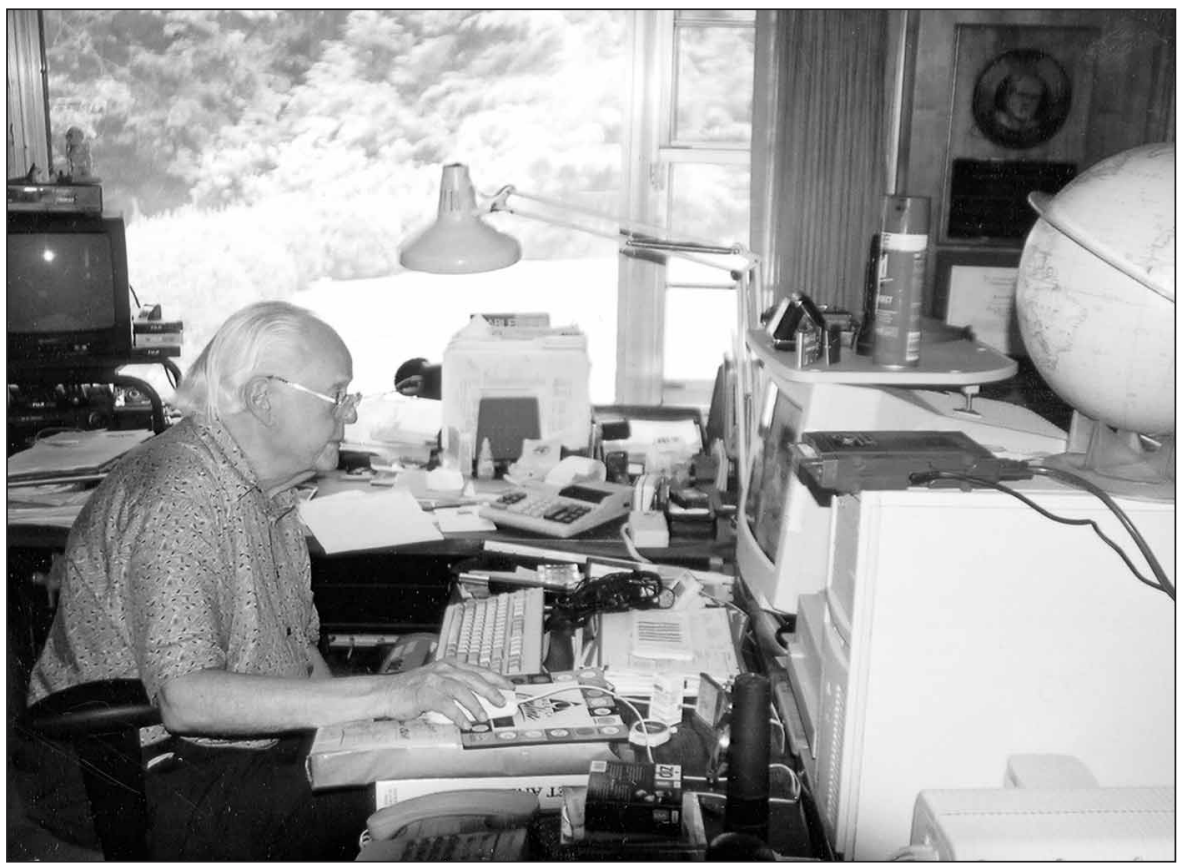

have to do with those glass lenses and tubes? So I went into the library to find out what an electron microscope was. There wasn't much to find, but I found enough of the theory to find it interesting.

Vibration was also a
problem-a truck coming
into the driveway was
enough to make the beam
unstable, so we had to isolate
the electron microscope.

So I was the one who took the risk, and it turned out later that there wasn't a single person except the chair of that department who thought the project was worthy. Others had done the calculations that showed if an electron beam hit the specimen, the energy of the electron beam needed to get sufficient resolution would end up burning the specimen.

So, to prove a point, our goal was to build the instrument and observe a razorblade edge to see how sharp an image we could obtain.

What was the design process for your first electron microscope?

Another graduate student, Cecil Hall, had preceded me by about a year and a half, and he had built a primitive type of electron microscope. It emitted electrons from the cathode, but because of what we call chromatic aberration, the elec- trons were emitted from the surface of the cathode at different velocities, so they focused at different points, producing a very poor image.

Albert Prebus from the University of Alberta and I worked with the instrument. We learned all we could from Cecil Hall's instruments, but we couldn't make them any better because the design was basically wrong. That's when we decided to build a high-voltage transmission type. That was at the end of 1937 . We spent the whole Christmas holiday designing that instrument, working all day and all night. After the holiday break, we had a discussion with Burton and Eirton, and they had enough of an adventurous spirit in them to let us do it.

You convinced them to switch to a high-voltage design? Burton didn't come to you?

No, no. We convinced them at this point. They gave us the go-ahead, but they said, "You can't spend a nickel." They were short of money and it was the Depression. We could use any equipment found in the building, and the machine shop. Being the new guys on the block, we were introduced to the new guy on the block in the machine shop who was a retired machinist named Fred. He worked there as a sort of retirement job. He was great, but he had spent his life repairing steam locomotives. He was wonderful on things that were big, but when we had five or six pieces that were only a centimeter in total dimension, he was hopeless. The head of the machine shop, then, agreed to show us how to use the machines, provided that we always worked together. It turned out that, years later, when I went to RCA and had a good machinist who would work with me, I never handed him something to make that I couldn't have made myself. He appreciated that because most of the electronics guys didn't know anything about machining, and they were always asking for impossibilities.

What kind of challenges did you run into while trying to make the Toronto instrument work?

Prebus and I built the first instrument in a few months, discovering that the theory was right, but that we had a million bugs. First, we had to determine whether we had any external magnetic fields and get rid of them because a magnetic field would make the electron beam oscillate. What really bothered us, though, were the streetcars. They worked on dc voltage and had a very strong magnetic output. The magnetic field increased as the streetcars approached, and then decreased. Vibration was also a problem-a truck coming into the driveway was enough to make 
the beam unstable, so we had to isolate the electron microscope.

The biggest problem, though, were the electrons themselves. If there was the slightest bit of insulating dirt on the inside of the column, the electrons would find it and charge it up, and as the particles of dirt charged up they would push the beam over. This was before clean rooms were invented. We had a major contamination problem in Toronto when we started. In Toronto, we used ground joints with grease that we made ourselves. We melted Vaseline and stirred in gum rubber. We slowly dissolved the gum rubber until we obtained a viscous and nicely rubberized grease that didn't give off a lot of oil. Everything we put in the electron microscope started to grow after a while from contamination when the electrons hit the oil molecules that floated around. Our vacuum wasn't good enough for an electron beam because it put a carbon deposit from the oil on everything. The electron beam charged this all the way through the system.

Any imperfection in the iron we put around the coil of the electron lens could distort the electron beam, causing an astigmatism, just like an astigmatism in the lens of your eye. We spent a couple of months trying to obtain pure iron, but we never could.

Finally, one night when I was half asleep, a thought struck me: If nature can mess up your lens by that little bit of eccentricity, you ought to be able to mess it up backwards to correct it. The next morning I put eight iron screws through the brass wall of the microscope into the gap of the electron lens. Before the day was over, I'd learned to work those screws in and out to cancel the astigmatism. I did exactly what you do with your eyeglasses. You get a cylindrical lens that's the right strength and put it in crossways to the astigmatism of your eye. However, I was doing this by pulling the magnetic field out to get the field so that it was centered. Overnight, that raised by resolving power to $10 \AA$, which meant I could go up to $250,000 \times$ magnification, steadily.

When did you start using your electron microscope to investigate what would today be called "materials" problems?

During an American Physical Society meeting held in June of 1938, we gave a demonstration. Almost immediately, the Canadian government was very interested in using the electron microscope to discover the structure of asbestos, which was suspected to be the cause of increased rates of cancer among asbestos miners. And there was the war effort on synthetic

\section{When he [Zworykin] asked how fast I could build one of these electron microscopes, I crossed my fingers behind my back and said, "Six months."}

rubber and the carbon blacks that were needed for synthetic rubber. Carbon black particles were much too small for a light microscope, so we did a lot of work for Columbia Carbon Company.

At that point, we were interested only in the size and shape of the particles. They turned out to be spherical and had a molecular structure that was way below the resolution of the light microscope. We could measure them quite accurately and determine their size distribution and their uniformity or non-uniformity. From this work, Columbia Carbon learned that certain sizes made a difference, and particle size became an important part of the company's design process.

\section{How did you end up working for Vladimir Zworykin at RCA?}

His way to hire me was simple. Both

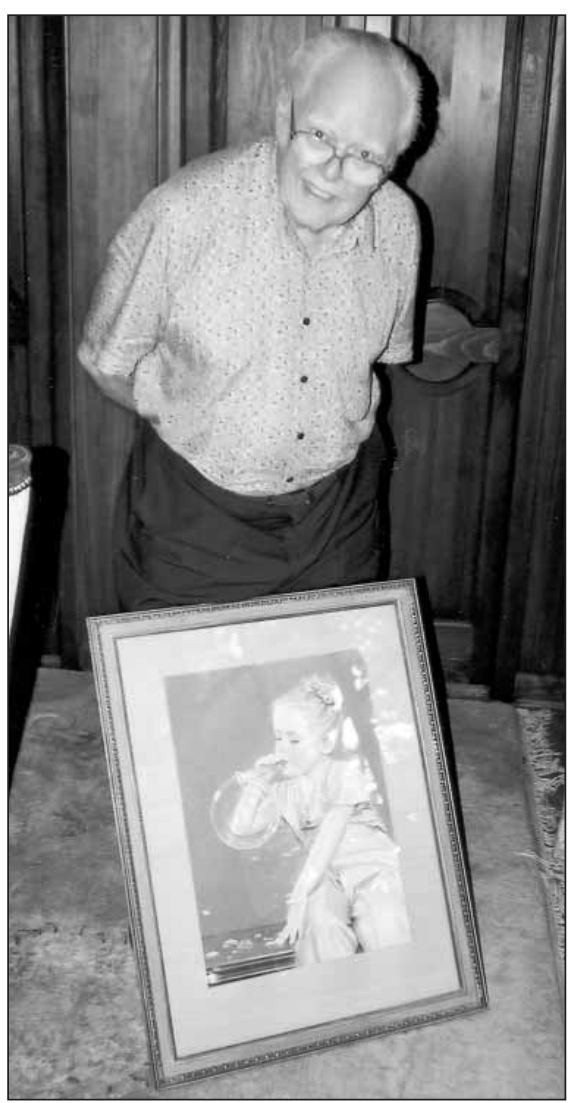

Prebus and I realized that this electron microscope was going to be useful all over the place. All of the industries that used small particles-the paint pigments, the ink pigments, asbestos fibers-would benefit from being able to see these powders. Also, in biology, the bacteriology and the virus studies could benefit from the electron microscope, and all we had was one "string and ceiling wax" instrument in a university lab. Others found out about this because we published some of our images as soon as we could make thin films and obtain samples that did not burn up.

We were in Canada in the middle of the Depression, and we found out very quickly that there wasn't a company in Canada that had either the money or the capabilities of making this instrument commercially because it needed a lot of different technologies. It needed the electron regulation technology, the vacuum technology, the electron optical technologies. We could only accomplish this in a large company like RCA, GE [General Electric], or Westinghouse.

We contacted GE and they interviewed us almost instantly. Unfortunately, they made a serious error. They spent a whole day telling us about their wonderful, glass-encased labs, and then, to add insult to injury, they told us about their retirement plans. We were 25 -year-old zealots who didn't care about retirement plans.

About three or four weeks later we received notice from RCA that they wanted to interview both Prebus and me. Then we waited another two to three weeks. Finally, I received an invitation to visit the RCA labs in Canada and New Jersey, but Prebus didn't. That mystified us. It turned out that Zworykin had spent all the money he had been given for the electron microscope project on Ladislaus Marton, who started there about a year before me, so he didn't have any money left to hire even one of us. But Zworykin figured that the accountants would take about nine months to catch up with him and he knew that I could do a pretty fast job.

Zworykin showed me around this lab in an abandoned factory building. It wasn't a glass-encased lab; it was literally dirty. The bridge over the Delaware River went by outside one of the windows a couple of feet away. He showed me things that were just out of this world. And I realized that they had something there. They were brilliant and really very impressive.

When he asked how fast I could build one of these electron microscopes, I crossed my fingers behind my back and said, "Six months."

As it happened, I built it in four months, and he was delighted because it turned 
out he was exactly right in his estimate- the accountants caught up with him nine months later. Meanwhile, we had five months to become famous.

When they found out, the accountants made him sell the prototype instrument that I designedthe experimental instrument for the lab that was being copied in the factory. We sold that to American Cyanamid Labs in Stamford, Connecticut, to make up for the design cost. It was $\$ 10,000$. That included my salary, a mechanical engineer, the two people who built the power supply, and a draftsman. Today it would take about $\$ 3$ million and about five years.

What was the biggest challenge you faced in designing a commercial electron microscope?

The rectifier tube put bobbles in the high voltage. Every time we changed voltage, the focus would change and the alignment would change. Also, the magnification changed at the same time as the focus. So the slightest variation in voltage or current in any of the lenses would ruin the image.

Art Vance and Jerry Morgan were the two geniuses who designed 50,000-V power supplies that used a battery standard, so they had the same constant output as a battery. Both the magnetic coils and the 50,000 high-voltage supply had one-part-in-100,000 stability. And the whole thing was in a small package.

So that stabilized the lenses and the electron gun.

Yes, the whole works. All they did was hand me two boxes; all I had to do was mount them. That was what made the four-month development time possible.

\section{In the early days you did a lot of work with biologists.}

Yes. I was one of the first, in Canada, to take pictures of bacteria. Once we discovered that a specimen made thin enough wouldn't burn-and the bacterium was thin enough to begin with-we started looking at them under the electron microscope. We could see the size and shape, but we didn't see any structure in the bacterium.

Wendell Stanley was a biologist who had worked for 11 years to isolate the tobacco mosaic virus and prove that it was the cause of the disease. Within 20 minutes with our first instrument [around September 1941], we showed Stanley what it took him 11 years to do using standard chemical and biological techniques.

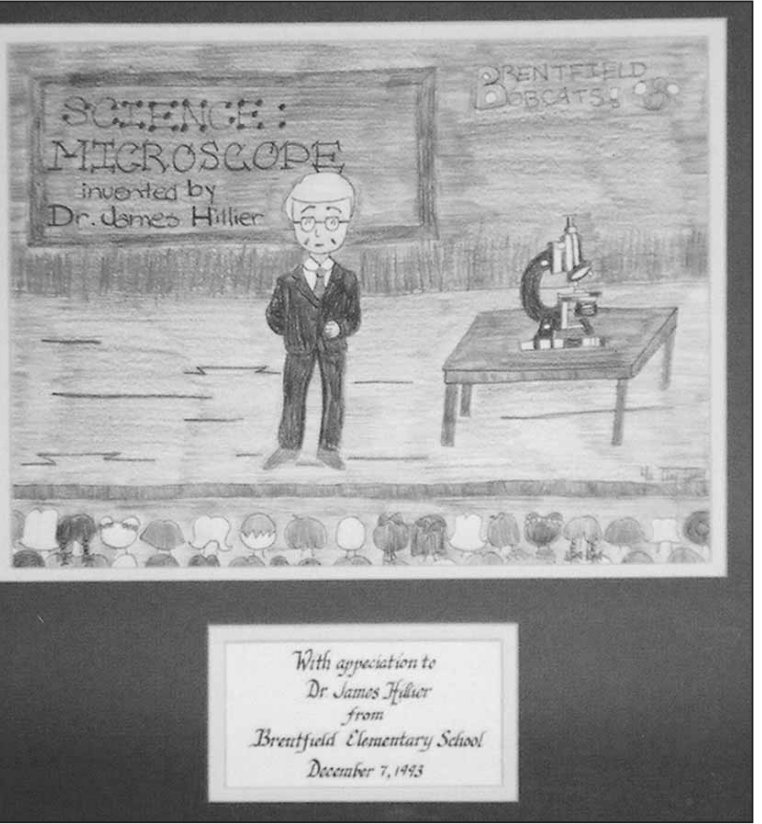

sion to go to Pittsburgh and talk to the people to get what they needed in the way of an exploratory research lab. I said I couldn't work without that. By then they trusted me enough so that I was the one guy who could communicate with both sides. I just struggled to try and find a research program. I got a few things going, but it just became obvious that they were all wrong. So we gave up. We finally mutually decided this was a mistake. They wanted me to be the chief engineer, but I wasn't interested. It was one year of unbelievable training-an absolute intensive course in running a research lab.

I returned to RCA and worked on various projects, like the videodisk. I also had the nasty chore of turning off the production of electron microscopes. It was 1960. The problem was that Japan still paid relatively low wages

We proved the width and the length, but we still could not see the structure-all we ever got was a fog. The reason we didn't see the internal structure was that our sample was still too thick-we had essentially 50 layers of sample, and the fog resulted from the electron scattering occurring in the sample. Later, when we had developed techniques and microtomes to make samples with one-fiftieth of the thickness of these early ones, we could see the fine structure.

\section{Why did you leave RCA?}

When I left in 1953, I had been in the electron microscope business for 16 years. I had taken the magnification from 1000x, matching that of the light microscope, up to $400,000 \times$ with the electron microscope.

I was doing so much outside work that I was setting up a bacteriology lab at the University of Pennsylvania and another electron microscope lab in the physics department at Cornell. I decided it was time to be a director rather than a technician, so I quit RCA and found a job as an assistant director for research for Westinghouse Air Brake. They had bought an electronics company, thinking it was the kind of research they ought to have, which it wasn't, but they did and they set it up as their fundamental corporate research lab.

About a month after I arrived, the director was fired, so I was made the director. It was absolutely crazy. The electronics subsidiary that they bought fought with the bosses in Pittsburgh to the point where nobody in the subsidiary was allowed to talk to anybody there. I finally got permis- compared with the United States, and they could hire five PhDs for what it cost me for one bachelor's-degree engineer. This was a highly technical competition and I couldn't compete under those conditions. So I told RCA it was time to shut it down. They already knew, because their sales were disappearing and the instruments from Japan were coming out like mad, and they were much better and more useful, with a lot of new gadgets.

What do you think is the most important skill to have as a director of research?

It depends, of course, on the organization and what you're trying to do. In a corporation like Westinghouse Air Brake, Union Switch and Signal, or RCA, the important thing is to hire good people and leave them alone. The director should help them, but stay out of their way. It is exactly the opposite of what the average research director thinks he ought to be doing. Recognizing when there is somebody who can help, and getting them together to help the job rather than promote your own importance-I just loved doing that sort of thing.

I believe that people come in two extremes. One is what I call the "thing" people and the other is the "people" people. They are absolutely the antithesis of one another. The "thing" people are the engineers who love the fact that they are working with a set of permanent, basic rules. In a marketing operation, we find "people" people because they love to play with the uncertainties. They are the people who take risks while the "thing" people do what they are told to do with the rules they already know. 
It seems like chance played a significant role throughout your career.

Not everything is due to just plain learning and doing the right things with that knowledge. Nearly everything that happened to me throughout my life was out of my control. I didn't buy the airport beside the apple orchard where I grew up, but someone did and that got me interested in airplanes and making a telescope, which led to my first experience with microscopy. Take the high school teacher, for another example. It's chance over which I had no control that I met him the year he started at my high school and set up the ham radio club. Getting the scholarship through him to study math and physics changed the direction of my life. Also the fact that I got in the electron microscope project because the director of the physics department retired in my first year of college, and all the projects he had started were over the hill when I started graduate school because he wasn't there anymore. That led me to find out what electron microscopes were all about. The fact that Prebus and I were told, because of the Depression, that we couldn't spend any money, made us learn how to make our own parts. That was the reason our instrument was a success. It was simplicity in itself.

Lately I've been telling teachers, "Look, in your lifetime, there are a lot of possibilities that happen and you have no control over those happenings." I've been trying to get the teachers to recognize that while they want to educate their students, they have to teach what the students are interested in, because sooner or later an opportunity will show up and the students will have the information they need to be able to identify it. The point is, with the information, they will see those opportunities. Otherwise, the opportunities float by like a cloud and the students don't know anything about them. I talk to the inventors inducted into the Inventors Hall of Fame, and they all tell me the same story.

I like to say, "A homerun is good for 30 seconds of recognition, and there are a lot of them. But an invention like the electron microscope can stay around for years."

Forever.

For my lifetime, if not forever. Most good inventions stay around for most of the lifetime of the inventor. If you think about it, there are a lot of advantages to going into a technical field. Both in money and in interest and in success and satisfaction. What I get out of all of this is the satisfaction of having done it.

When asked whether he has any regrets, Dr. Hillier said, "My hobby is still my work." He is a member of the board of directors of the National Inventors Hall of Fame in Akron, Ohio, where he encourages young students to explore their creative, inventive talents. He also heads the James Hillier Foundation, which he established in 1992 to provide college scholarships to worthy science students from Brant County, Ontario. It is his way of returning the favor of his geography teacher.

Interview by Tim Palucka, MRS Bulletin Associate Technical Editor

This work was supported by the Dibner Institute/Burndy Library and Sloan Foundation Program for the History of Recent Science and Technology on the Web:

\section{2003 3 Materials Research Society
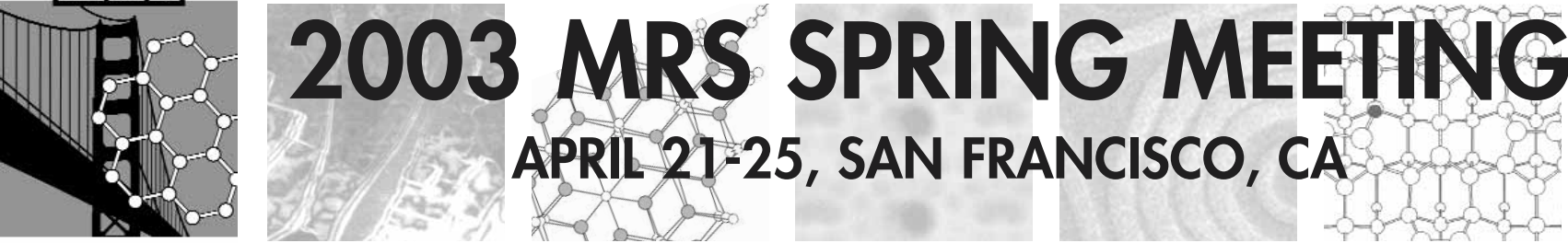

The 2003 Materials Research Society Spring Meeting will be held April 21-25, 2003, in San Francisco, California, at the San Francisco Marriott and Argent Hotels. The meeting will include 25 symposia that highlight new advances in the understanding, synthesis, and application of materials in diverse fields.

\section{CONTACT INFORMATION}

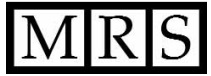

Materials Research Society

506 Keystone Drive

Warrendale, PA 15086-7573 USA

Tel: $724-779-3003$

Fax: $724-779-8313$ (general)

724-779-3030 (abstract submittal)

E-mail: info@mrs.org

\section{Plan now to attend!}

\section{SCHEDULED SYMPOSIA}

\section{ELECTRONIC AND OPTICAL MATERIALS}

A: Amorphous and Nanocrystalline Silicon-Based Films-2003

B: Compound Semiconductor Photovoltaics

C: New Applications for Wide-Bandgap Semiconductors

D: CMOS Front-End Materials and Process Technology

E: Materials, Technology, and Reliability for Advanced Interconnects and Low- $k$ Dielectrics

F: Chemical-Mechanical Planarization

G: Integration of Heterogeneous Thin-Film Materials and Devices

$\mathrm{H}$ : Flexible Electronics-Materials and Device Technology

I: Optoelectronics of Group-IV-Based Materials

J: Microphotonics, Nanophotonics, and Photonic Crystals

\section{MOLECULAR MATERIALS AND BIOMATERIALS}

K: Molecular-Scale Electronics and Optoelectronics

L: Organic and Polymeric Materials and Devices

M: Nanotube-Based Devices

$\mathrm{N}$ : Biomicroelectromechanical Systems (BioMEMS)

O: Materials Inspired by Biology

\section{NANOSTRUCTURED MATERIALS}

P. Self-Assembled Nanostructured Materials

Q: Unconventional Approaches to Nanostructures with Applications in Electronics, Photonics, Information Storage, and Sensing

R: Nanomagnetism

S: Nanoscale Thermal Transport-From Fundamentals to Devices

T: Nanostructuring Materials with Energetic Beams

U: Mechanical Properties Derived from Nanostructuring Materials

GENERAL

V: Semiconductor Spintronics II

W: Multiscale Phenomena in Materials-Experiments and Modeling Related to Mechanical Behavior

$X$ : Frontiers of Materials Research

Y: Advanced Optical Processing of Materials

Z: Mechanisms in Electrochemical Deposition and Corrosion

For symposium descriptions and updated meeting information, visit the MRS Web site:

www.mrs.org/meetings/spring2003/ 